\title{
Students and Housewives: Differences in Susceptibility to Reference Group Influence
}

\author{
C. WHAN PARK \\ V. PARKER LESSIG*
}

\begin{abstract}
Two different samples consisting of housewives and students, respectively, were examined in terms of differences in their susceptibility to reference group influence. The results reveal significant differences between housewives and students in terms of the influence which the three types of reference groups have upon brand selection. The findings raise a serious question concerning the external validity of studies which use students as subjects yet make generalizations to a broader population base.
\end{abstract}

$\mathrm{M}$ uch of the experimental research conducted in psychology and consumer behavior has used college students as respondents. This raises a question concerning the external validity of the experimental results. The response differences between students and housewives have been examined in several studies (Sheth 1970; Khera and Benson 1970; Enis, Cox, and Stafford 1972; Shuptrine 1975; Copeland et al. 1973; Enis and Stafford 1969). None of these studies provided unequivocal conclusions regarding differences between the two populations. The following are typical of conclusions reached:

"The state of knowledge in this area remains woefully inadequate" (Khera and Benson 1970, p. 531);

"The results are somewhat disappointing, to say the least, since the data do not provide a clear answer to our question" (Enis, Cox, and Stafford 1972, p. 73);

"These results, as in previous research, tend to be inconclusive" (Shuptrine 1975, p. 389).

Arndt (1971) reported that college students and their parents differ along "perceptual variables" where it is not clear whether the difference is a function of (a) the different kinds of items examined or (b) the differences in the usage of these items across the students and

* C. Whan Park is Assistant Professor and V. Parker Lessig is Professor and Director of Doctoral Programs, both at School of Business, The University of Kansas, Lawrence, KS 66045. This research was supported by grants from the University of Kansas General Research Fund and from the University of Kansas School of Business Research Fund provided by the Fourth National Bank and Trust Company, Wichita, KS. their parents. In addition to the inconclusive findings, there has been no systematic treatment of the locus of the level of response differences, that is, process related differences, or specific situation bounded response differences between the two types of groups.

The objective of the present study is to examine differences between students and housewives with respect to process-related differences, specifically, to examine differences between the two populations in terms of their susceptibility to reference group influence. The degree of reference group influence is examined for each of 20 products, and for three different types of reference group influence.

\section{REFERENCE GROUP INFLUENCE}

In the present study, a reference group is defined to be an actual or imaginary individual or group conceived of having significant relevance upon an individual's evaluations, aspirations, or behavior. Within this definition, three motivational influences of reference groups will be examined-informational, value expressive, and utilitarian.

\section{Informational Reference Group Influence}

This reference group influence is similar to the informational or comparative influence suggested by Deutsch and Gerard (1955), although their definition is not specific. It may be described by processes such as Asch's conviction (1952), Jahoda's consentience (1972), or Kelman's internalization process (1961). An influence is accepted (internalized) if it is perceived 
as enhancing the individual's knowledge of his environment and/or his ability to cope with some aspect of this environment, e.g., purchasing a product. The information source most readily internalized is the one perceived as being credible (Kelman 1961; Jones and Gerard 1967; Jahoda 1972). As the Yale group studies concluded (Hovland and Weiss 1951; Hovland, Janis, and Kelley 1953; Janis et al. 1959), sources of high credibility play a very significant role in determining conformity.

An individual may use an informational reference group in two different ways. One is to actively search for information from opinion leaders or from a group with the appropriate expertise. Second, the individual makes an inference by observing the behavior of significant others. As implied by attribution theory (Jones et al. 1972), the individual attributes to the product's quality, the product's purchase or endorsement by an individual or group. Consistent with the comparative appraisal of Jones and Gerard (1967), this type of information search requires no actual interaction between the individual and the reference group.

\section{Utilitarian Reference Group Influence}

This reference group influence is similar to the normative influence (Deutsch and Gerard 1955), the conformity concept of "it-is-dangerous-not-to-conform" (Asch 1952), and the compliance process (Kelman 1961; Jahoda 1972). An individual in a product purchasing situation would be expected to comply with the preferences or expectations of another individual or group if:

1. He perceives that they mediate significant rewards or punishments;

2. He believes that his behavior will be visible or known to these others; and

3. He is motivated to realize the reward or to avoid the punishment.

A crucial difference between the utilitarian reference group influence examined in this paper and the normative social influences just cited is that most of these other social influences are derived from explicit rewards and punishments which accompany specific group memberships and specifically defined norms.

\section{Value-Expressive Reference Group Influence}

This reference group influence relates to an individual's motive to enhance or support his selfconcept. Such an individual would be expected to associate himself with positive referents and/or dissociate himself from negative referents (Kelman 1961).

The value-expressive reference group influence is characterized by two different processes. First, an individual utilizes reference groups to express himself or bolster his ego. In this case, there should be a consistency between the desire to express one's self and the psychological image attached to the reference group.

Second, an individual is influenced by a valueexpressive reference group because of his simple affect (liking) for that group. This does not require consistency between one's self image and the psychological image attached to the reference group. Thus, an individual responds (e.g., adopts the recommendations) to the reference group although the content of responses (e.g., acceptance of recommendations) is irrelevant to the group.

\section{REASONS FOR REFERENCE GROUP DIFFERENCES BETWEEN STUDENTS AND HOUSEWIVES}

Motivational factors were emphasized as one of the determinants of perceptual processes (Bruner 1958) and as a critical element in explaining cognitive consistence theories (e.g., Katz 1968; Davis 1968; Kelman and Baron 1968). This leads to the speculation that if there are differences in needs or motivation among different people, there should also be process related differences among them. There is theoretical support for the existence of need differences between the two samples (students and housewives) in terms of their response to reference group influence. ${ }^{1}$

First, need differences may exist due to differences in their age distributions. An age difference quite often accompanies a difference in (a) the amount of learning (i.e., the degree of familiarity with the product), (b) the accommodation of information (Jacoby et al. 1974), and (c) risk handling (Kogan and Wallach 1967). For example, Berning and Jacoby (1974) attributed differences in information accommodation between two samples to differences in years of shopping experience. This learning or experience difference is expected to bear directly upon reference group influence. As Hochbaum (1954) indicated, a person's dependence on social referents is inversely related to his confidence in his competence to judge the issue. Another factor is that young people, such as college students, may be more susceptible to reference group influence since they would be expected to have more limited capacity to cope with uncertainty and risk than more mature individuals, such as housewives.

Second, need differences may exist between students and housewives due to differences in their immediate social surroundings and their daily activity

\footnotetext{
1 Throughout the remainder of this paper no distinction between male and female students is made. However, as will be shown in a later footnote, sex differences among students did not affect the study's findings.
} 
patterns. We suspect that substantial differences may exist between students and housewives in terms of the frequency of informal social contacts, the intensity of peer pressure on one's choice behavior, the visibility of social approval in a group, and the rigidity of the group structure in which they interact. For example, we would expect students to have more frequent social contacts than housewives; we would also expect the group structure in which students interact (e.g., sororities, fraternities, and dormitories) to impose more rules and norms than is the case of groups in which housewives interact. The visibility of one's behavior in a rigid group structure would make students more responsive to group influence (Deutsch and Gerard 1955).

Also, the availability of frequent informal social contact (to which students are exposed perhaps more than housewives) facilitates obtaining information from others and aids in the social confirmation and legitimization of one's behavior. These informal groups play an important role in risk reduction. Several studies support the position that peers are a dominant influence on the behavior of young adults (Teter 1966; Kanter 1970; Scott 1974).

Third, need differences between students and housewives may exist due to differences in their stages in the socialization process. Specifically, hedonism (Rosenberg 1968) may be stronger among students than among housewives. Young people, like students, are in a continuous socialization process in which they are forming an ego, expressing themselves to an outside world, and testing their acceptability to others. Doing these things involves trial and error learning of ego expression and self-realization, both of which are part of the socialization process (Scott 1974). Egorelated consumption and a peer group's influence on it is perhaps best described by Reisman and Rosenborough (1955) who state that children learn "consumption necessities" from their parents but "affective consumption [styles and moods of consumption]" from peers.

An additional point is that although socialization is a lifelong process, the intensity of socialization in terms of the amount of learning should be much stronger at an earlier age than at a later age (Brim 1968). Two specific implications from this are that (a) socialization is a more active process among students than among housewives, and (b) students are more likely to have yet-to-be-solidified cognitive structures than housewives, thus making students more susceptible to changes in attitude and behavior (Feather 1971).

\section{METHOD}

\section{Manifestation Statements}

The authors and a graduate assistant exchanged ideas concerning the probable behavior which consumers manifest in conjunction with significant others. Furthermore, one of the authors conducted intensive informal interviews with one graduate and five undergraduate students relating to probable reference group behavior. Specifically, each student was instructed on the theoretical nature of each type of reference group influence and then asked to describe the behavior which he and others have likely exhibited in conjuction with each type of influence. Based upon these interviews and from general inferences in the literature, 18 statements relating to reference group influence were written. These statements were designed to be general enough to encompass different forms of behavior underlying a given type of reference group influence, yet specific enough to reflect only one motivational function.

The 18 statements were examined in a pretest using 22 consumer behavior students who were already familiar through class lectures with the different types of reference group influence. For 14 statements, the students' responses were consistent with our expectations. Since the 14 statements covered all three forms of reference group influence, only these statements were used in the main study, though some were changed slightly based upon pretest feedback. Of these revised 14 statements (see exhibit), five of these statements relate to the informational reference group influence, four to the utilitarian influence, and five to the value-expressive influence.

To test the validity of the revised statements, the student pretest was followed by a similar pretest consisting of 42 adult subjects living in the Kansas City metropolitan area, randomly selected from a telephone directory. After being informed through printed descriptive material of the three different forms of reference group influence, the subjects in this adult pretest were able to correctly associate the manifestation statements with the appropriate influence. ${ }^{2}$

\section{Subjects}

Subjects from two different populations were selected for examination in the main study. For the first set of subjects, 162 housewives living in Topeka, Kansas area were randomly selected (from the telephone directory) as possible study participants. Each prospective respondent was contacted by telephone and informed that they would be paid two dollars for their participation. A total of 145 individuals indicated a willingness to cooperate and were therefore sent a questionnaire and a cover letter; of these, 100 completed and returned all questions. ${ }^{3}$

\footnotetext{
${ }^{2}$ The construct validity of the 14 manifestation statements was measured using a test outlined by Campbell and Fiske. This test was run on data collected in the main study (and not from data obtained from pretest subjects) and made use of reference group scores yet to be discussed. Discussion of this validation is presented in the appendix.

${ }^{3}$ A systematic investigation of the nonresponses was not performed. These might be due to such "random" factors as "time problems," "forgetting to do it," etc., or they may be due to some
} 
The second set of subjects consisted of unmarried junior and senior marketing students at the University of Kansas. Each student's participation was under one of two different response situations. Specifically, 51 students responded to the questionnaire in class. In order to examine the possible impact of two different response settings, an additional 52 students were asked to complete the questionnaire at home. Of these 52 students, 37 returned responses to all questions. ${ }^{4}$

\section{Measuring Reference Group Influence}

Influences associated with a number of different types of products were examined. The products selected vary along two types of product classification (Enis 1974): loyal (to brand) vs. not loyal (to brand) and shopping vs. convenience. This set also includes representative products from Bourne's (1956) study in which he presented a matrix categorizing reference group influences upon products and brands. Specifically, the following 20 products were examined in this study: automobiles, beer, canned peaches, cigarettes, clothing, coffee, color television, facial soap, furniture, hamburger substitute, headache remedy, home air conditioner, insurance, laundry soap, low phosphate detergent, magazine or book selection, mouthwash, refrigerator, physician selection, and transistor radios.

The subjects were presented the 14 reference group manifestation statements with a listing of the 20 products, and asked to indicate, for each product, the extent to which the situation described by the statement is relevant to a consumer's alternative (e.g., brand) selection. In doing this, they were to assume that the individual has decided to purchase the product but has not yet decided which brand of the product to buy. The following response categories were provided for each statement-product combination: highly relevant $(\mathrm{H})$, medium relevance $(\mathrm{M})$, low relevance (L), and not relevant (NR). ${ }^{5}$

unknown critical factor which would cause the housewife sample to be nonrepresentative.

Late communication was ultimately received from six subjects classified as nonrespondents. Two of these subjects indicated that they did not complete the questionnaire because they found it too difficult to understand; three said they could not fulfill their promises to participate due to personal problems (i.e., illness or husband's job transfer); and one subject returned a completed questionnaire but too late to be used in the study.

${ }^{4}$ The student sample used in this study may not be representative of all students since these subjects were not randomly selected from the student population and since business students may be different from other types of college students. The study's findings should, therefore, be interpreted in terms of differences between housewives and business students.

${ }^{5}$ Six months after data from 100 housewives were collected, 20 of these respondents were randomly selected for a reliability retest. Thirteen of these housewives agreed to participate and were sent the same questionnaire administered earlier and paid an additional two dollars. The correlation between the initial and the retest responses on the 280 variables included in the study, i.e.,

\section{EXHIBIT}

STATEMENTS MANIFESTING REFERENCE GROUP FUNCTIONS

\section{Informational influence}

$A_{1}$ The individual seeks information about various brands of the product from an association of professionals or independent group of experts.

$A_{2}$ The individual seeks information from those who work with the product as a profession.

$A_{3}$ The individual seeks brand related knowledge and experience (such as how Brand A's performance compares to Brand B's) from those friends, neighbors, relatives, or work associates who have reliable information about the brands.

$A_{4}$ The brand which the individual selects is influenced by observing a seal of approval of an independent testing agency (such as Good Housekeeping).

$A_{5}$ The individual's observation of what experts do influences his choice of a brand (such as observing the type of car which police drive or the brand of TV which repairmen buy).

\section{Utilitarian influence}

$B_{1}$ To satisfy the expectations of fellow work associates, the individual's decision to purchase a particular brand is influenced by their preferences.

$B_{2}$ The individual's decision to purchase a particular brand is influenced by the preferences of people with whom he has social interaction.

$B_{3}$ The individual's decision to purchase a particular brand is influenced by the preferences of family members.

$B_{4}$ The desire to satisfy the expectations which others have of him has an impact on the individual's brand choice.

\section{Value-expressive influence}

$C_{1}$ The individual feels that the purchase or use of a particular brand will enhance the image which others have of him.

$C_{2}$ The individual feels that those who purchase or use a particular brand possess the characteristics which he would like to have.

$C_{3}$ The individual sometimes feels that it would be nice to be like the type of person which advertisements show using a particular brand.

$C_{4}$ The individual feels that the people who purchase a particular brand are admired or respected by others.

$C_{5}$ The individual feels that the purchase of a particular brand helps him show others what he is, or would like to be (such as an athlete, successful businessman, good mother, etc.).

14 manifestation statements for each of 20 products, for the 13 housewives ranged from 0.78 to 0.43 , all significant at the 0.001 level.

A similar reliability retest was performed on student subjects two months after the data for the main study were collected. Again, 13 of the original respondents were randomly selected and paid two dollars for their participation. The 13 test-retest correlations for these subjects were all significant at the 0.001 level and ranged from 0.91 to 0.56 . 
TABLE 1

COMPARISION OF REFERENCE GROUP INFLUENCE SCORES

\begin{tabular}{|c|c|c|c|c|c|c|c|c|c|}
\hline \multirow[b]{2}{*}{ Product } & \multicolumn{3}{|c|}{ Informational } & \multicolumn{3}{|c|}{ Utilitarian } & \multicolumn{3}{|c|}{ Value-expressive } \\
\hline & $\begin{array}{l}\text { Students } \\
\text { in-class }\end{array}$ & Housewives & $\begin{array}{l}\text { Students } \\
\text { at-home }\end{array}$ & $\begin{array}{l}\text { Students } \\
\text { in-class }\end{array}$ & Housewives & $\begin{array}{l}\text { Students } \\
\text { at-home }\end{array}$ & $\begin{array}{l}\text { Students } \\
\text { in-class }\end{array}$ & Housewives & $\begin{array}{l}\text { Students } \\
\text { at-home }\end{array}$ \\
\hline Headache remedy & 3.76 & 3.38 & 3.59 & 3.49 & 2.98 & 3.08 & 2.88 & 2.42 & 2.51 \\
\hline Beer & 3.07 & 2.60 & 2.84 & 3.72 & 3.08 & 3.62 & 3.53 & 2.71 & 3.62 \\
\hline Color television & 3.90 & 3.84 & 4.00 & 3.75 & 3.51 & 3.51 & 3.67 & 3.43 & 3.73 \\
\hline Clothing & 3.50 & 3.45 & 3.32 & 3.88 & 3.59 & 3.86 & 3.94 & 3.61 & 3.92 \\
\hline Laundry soap & 3.23 & 2.99 & 3.05 & 2.80 & 2.53 & 2.68 & 2.64 & 2.42 & 2.22 \\
\hline Hamburger substitute & 2.98 & 2.56 & 2.92 & 3.09 & 2.33 & 2.59 & 2.33 & 1.93 & 2.19 \\
\hline Automobile & 3.96 & 3.85 & 3.92 & 3.90 & 3.70 & 3.95 & 3.96 & 3.65 & 3.97 \\
\hline Furniture & 3.50 & 3.51 & 3.35 & 3.60 & 3.59 & 3.59 & 3.67 & 3.52 & 3.70 \\
\hline Facial soap & 3.21 & 2.89 & 2.84 & 2.98 & 2.94 & 2.76 & 3.29 & 2.85 & 3.00 \\
\hline Air conditioner & 3.74 & 3.75 & 3.84 & 3.33 & 3.21 & 2.95 & 3.27 & 3.14 & 3.11 \\
\hline Insurance & 3.80 & 3.71 & 3.81 & 3.55 & 3.38 & 3.22 & 3.29 & 3.08 & 3.14 \\
\hline Mouthwash & 3.17 & 2.92 & 2.86 & 3.33 & 3.02 & 3.11 & 3.35 & 2.57 & 3.05 \\
\hline Coffee & 3.23 & 2.88 & 2.86 & 3.43 & 3.28 & 3.27 & 2.80 & 2.58 & 2.62 \\
\hline Refrigerator & 3.66 & 3.70 & 3.68 & 3.35 & 3.23 & 2.89 & 3.12 & 3.14 & 3.22 \\
\hline Physician selection & 3.86 & 3.72 & 3.95 & 3.76 & 3.50 & 3.54 & 3.27 & 3.18 & 3.30 \\
\hline Canned peaches & 2.47 & 2.49 & 2.49 & 2.84 & 2.54 & 2.51 & 2.02 & 1.99 & 1.89 \\
\hline Radio & 3.31 & 3.16 & 3.38 & 3.04 & 2.79 & 2.81 & 2.88 & 2.64 & 2.81 \\
\hline Detergent & 3.05 & 2.88 & 2.87 & 2.57 & 2.35 & 2.24 & 2.63 & 2.17 & 2.24 \\
\hline Books or magazines & 3.29 & 3.00 & 3.03 & 3.47 & 3.36 & 3.43 & 3.41 & 3.08 & 3.49 \\
\hline Cigarettes & 3.01 & 2.49 & 2.97 & 3.10 & 2.68 & 3.19 & 3.31 & 2.51 & 3.35 \\
\hline
\end{tabular}

For each subject, three scores were obtained for each of the 20 products indicating the relevance of each of the three types of reference group influence. To illustrate the group influence scores, consider the informational reference group influence. For a given subject, the degree of that group influence associated with a particular product is defined as the highest response for that product given on any of the five statements of that influence. ${ }^{6}$ This produced, for each product, a distribution of 100 responses for the housewife sample and of 88 responses for the student sample. Coding individual responses within a distribution as 4 for $\mathrm{H}, 3$ for $\mathrm{M}, 2$ for $\mathrm{L}$, and 1 for $\mathrm{NR}$, the relevance of that group influence for a given product is found by averaging across the subjects, In a manner identical to that just described, scores for the 20 products were calculated which reflect the influence on brand (or alternative) selection of utilitarian and by value-expressive reference groups and appear in Table 1 .

\section{FINDINGS}

The informational, utilitarian, and value-expressive reference group influence scores of the 51 in-class students were compared to the corresponding scores of the 100 housewives by $60 t$ tests (three reference group influence scores on each of 20 products). The same comparison procedure was also followed in com-

\footnotetext{
${ }^{6}$ Note that more than one response by a subject at the highest response level, e.g., $M$, does not increase the relevance of the informational reference group influence. This situation would only indicate that there are several channels through which "knowledge" (of perhaps medium relevance) can be obtained.
}

paring the 37 at-home students and the 100 housewives. This examination was critical since, in most cases, housewives respond to questionnaires at home while students typically provide responses in class. Fifteen of the 60 comparisons between the at-home students and the housewives and 22 of the $60 \mathrm{com}$ parisons between the in-class students and the housewives showed significant differences at the 0.05 level. These differences are presented in Tables 2 and 3. Fifteen and 22 significant $t$ tests are significantly greater (well beyond the 0.00001 level) than the expected number of 3 under the hypothesis of no difference. Thus, across all three types of reference group influence, the alternative hypotheses are accepted which state that the reference group influence scores of housewives differ from those of students at-home and from those of the in-class students. Furthermore, if each type of reference group influence is examined separately, the number of significant $t$ tests for each influence type (i.e., informational, utilitarian, and value-expressive) for both the housewife vs. at-home student comparisons and the housewife vs. in-class student comparisons is significantly greater than that expected if, for that type of reference group influence, the scores of housewives and students were the same.

The informational, utilitarian, and value-expressive reference group influence scores of the 51 in-class students were compared to the corresponding scores on the 37 at-home students. Nine of the 60 comparisons showed significant differences at the 0.05 level. Response differences were found for the following product-reference group sets: informational reference group influence-facial soap and coffee; utilitarian 
TABLE 2

AREAS OF SIGNIFICANT DIFFERENCE BETWEEN STUDENT AT-HOME AND HOUSEWIFE REFERENCE GROUP INFLUENCE

\begin{tabular}{|c|c|c|c|}
\hline \multirow[b]{2}{*}{ Product } & \multicolumn{3}{|c|}{$\begin{array}{l}\text { Reference group influence } \\
\text { score }\end{array}$} \\
\hline & $\begin{array}{l}\text { House- } \\
\text { wife }\end{array}$ & $\begin{array}{l}\text { Stu- } \\
\text { dent }\end{array}$ & $t$ value \\
\hline \multicolumn{4}{|c|}{ Informational influence } \\
\hline $\begin{array}{l}\text { Color television } \\
\text { Hamburger substitute } \\
\text { Physician selection } \\
\text { Cigarettes }\end{array}$ & $\begin{array}{l}3.84 \\
2.46 \\
3.72 \\
2.49\end{array}$ & $\begin{array}{l}4.00 \\
2.92 \\
3.95 \\
2.97\end{array}$ & $\begin{array}{l}-2.46^{\mathrm{a}} \\
-2.33^{\mathrm{b}} \\
-2.27^{\mathrm{b}} \\
-2.32^{\mathrm{b}}\end{array}$ \\
\hline \multicolumn{4}{|c|}{$\underline{\text { Utilitarian influence }}$} \\
\hline $\begin{array}{l}\text { Beer } \\
\text { Clothing } \\
\text { Automobiles } \\
\text { Cigarettes }\end{array}$ & $\begin{array}{l}3.08 \\
3.59 \\
3.70 \\
2.68\end{array}$ & $\begin{array}{l}3.62 \\
3.86 \\
3.95 \\
3.19\end{array}$ & $\begin{array}{l}-2.72^{\mathrm{a}} \\
-2.07^{\mathrm{b}} \\
-2.38^{\mathrm{a}} \\
-2.31^{\mathrm{b}}\end{array}$ \\
\hline \multicolumn{4}{|c|}{ Value-expressive influence } \\
\hline $\begin{array}{l}\text { Beer } \\
\text { Color television } \\
\text { Clothing } \\
\text { Automobiles } \\
\text { Mouthwash } \\
\text { Books or magazines } \\
\text { Cigarettes }\end{array}$ & $\begin{array}{l}2.71 \\
3.43 \\
3.61 \\
3.65 \\
2.57 \\
2.57 \\
2.51\end{array}$ & $\begin{array}{l}3.62 \\
3.73 \\
3.92 \\
3.97 \\
3.05 \\
3.49 \\
3.35\end{array}$ & $\begin{array}{l}-4.36^{\mathrm{a}} \\
-2.05^{\mathrm{b}} \\
-2.44^{\mathrm{a}} \\
-2.61^{\mathrm{a}} \\
-2.20^{\mathrm{b}} \\
-2.23^{\mathrm{b}} \\
-3.63^{\mathrm{a}}\end{array}$ \\
\hline
\end{tabular}

a Significant at .01 level.

${ }^{b}$ Significant at .05 level.

reference group influence-headache remedy, hamburger substitute, air conditioner, insurance, and refrigerator; value-expressive reference group influence-laundry soap and detergent. Nine significant differences are significantly greater than that which would be expected (i.e., 3) if location had no effect on the student responses. Although there were no consistent directional response differences for these nine products, the significant differences do suggest that response setting does have some effect upon subject responses. ${ }^{7,8}$

Finally, both of the student samples, i.e., in-class and at-home, were combined to form a single sample; the reference group influence scores of this combined student sample were compared to the corresponding

\footnotetext{
${ }^{7}$ The differences noted do not lead to meaningful interpretation regarding the nature of the at-home vs. the in-class effect.

${ }^{8}$ In addition to examining student responses on the basis of response location, the reference group influence scores of the 32 female student subjects were compared to the scores of the 56 male subjects through $60 t$ tests like those just discussed. Only two of these $t$ tests were significant at the 0.05 level indicating that the sex of the student subjects did not affect their reference group influence scores and would therefore not be a factor in the studenthousewife comparison.
}

housewife scores. As Table 4 reveals, 22 of the 60 comparisons showed significant differences at the 0.05 level.

\section{SUMMARY AND CONCLUSIONS}

The results of this study reveal that, regardless of response setting, significant differences exist between students and housewives in terms of the influence of reference groups on brand (or other product alternative, e.g., model) selection. Where significant differences exist between students and housewives, students are without exception consistently more susceptible to reference group influence. This observation is consistent with the expectations drawn from the paper's theoretical section.

It should also be noted that significant differences (9 out of 60 comparisons) were found between the responses of students at home and those of the in-class

TABLE 3

AREAS OF SIGNIFICANT DIFFERENCE BETWEEN STUDENT IN-CLASS AND HOUSEWIFE REFERENCE GROUP INFLUENCE

\begin{tabular}{|c|c|c|c|}
\hline \multirow[b]{2}{*}{ Product } & \multicolumn{3}{|c|}{$\begin{array}{l}\text { Reference group influence } \\
\text { score }\end{array}$} \\
\hline & $\begin{array}{l}\text { House- } \\
\text { wife }\end{array}$ & $\begin{array}{l}\text { Stu- } \\
\text { dent }\end{array}$ & $t$ value \\
\hline \multicolumn{4}{|c|}{ Informational influence } \\
\hline $\begin{array}{l}\text { Headache remedy } \\
\text { Beer } \\
\text { Hamburger substitute } \\
\text { Coffee } \\
\text { Cigarettes }\end{array}$ & $\begin{array}{l}3.38 \\
2.60 \\
2.46 \\
2.88 \\
2.49\end{array}$ & $\begin{array}{l}3.76 \\
3.08 \\
2.98 \\
3.23 \\
3.01\end{array}$ & $\begin{array}{l}-2.83^{\mathrm{a}} \\
-2.72^{\mathrm{a}} \\
-3.02^{\mathrm{a}} \\
-2.12^{\mathrm{b}} \\
-2.79^{\mathrm{a}}\end{array}$ \\
\hline \multicolumn{4}{|c|}{ Utilitarian influence } \\
\hline $\begin{array}{l}\text { Headache remedy } \\
\text { Beer } \\
\text { Clothing } \\
\text { Hamburger substitute } \\
\text { Automobile } \\
\text { Physician selection } \\
\text { Cigarettes }\end{array}$ & $\begin{array}{l}2.98 \\
3.08 \\
3.59 \\
2.33 \\
3.70 \\
3.50 \\
2.68\end{array}$ & $\begin{array}{l}3.49 \\
3.72 \\
3.88 \\
3.09 \\
3.90 \\
3.76 \\
3.09\end{array}$ & $\begin{array}{l}-2.99^{\mathrm{a}} \\
-3.77^{\mathrm{a}} \\
-2.56^{\mathrm{a}} \\
-3.93^{\mathrm{a}} \\
-2.22^{\mathrm{b}} \\
-1.98^{\mathrm{b}} \\
-2.10^{\mathrm{b}}\end{array}$ \\
\hline
\end{tabular}

Value-expressive influence

\begin{tabular}{llll} 
Headache remedy & 2.42 & 2.88 & $-2.46^{\mathrm{a}}$ \\
Beer & 2.71 & 3.53 & $-4.39^{\mathrm{a}}$ \\
Clothing & 3.61 & 3.94 & $-3.02^{\mathrm{a}}$ \\
Hamburger substitute & 1.93 & 2.33 & $-2.18^{\mathrm{b}}$ \\
Automobile & 3.65 & 3.96 & $-2.83^{\mathrm{a}}$ \\
Facial soap & 2.85 & 3.29 & $-2.47^{\mathrm{a}}$ \\
Mouthwash & 2.57 & 3.35 & $-4.12^{\mathrm{a}}$ \\
Detergent & 2.17 & 2.63 & $-2.46^{\mathrm{a}}$ \\
Book or magazines & 3.08 & 3.41 & $-2.05^{\mathrm{b}}$ \\
Cigarettes & 2.51 & 3.31 & $-3.99^{\mathrm{a}}$ \\
\hline
\end{tabular}

a Significant at .01 level

b Significant at .05 level. 
TABLE 4

COMPARISON OF REFERENCE GROUP INFLUENCE SCORES

\begin{tabular}{|c|c|c|c|c|c|c|}
\hline \multirow[b]{2}{*}{ Product } & \multicolumn{2}{|c|}{ Informational } & \multicolumn{2}{|c|}{ Utilitarian } & \multicolumn{2}{|c|}{ Value-expressive } \\
\hline & Students ${ }^{a}$ & Housewives $^{b}$ & Students $^{\mathbf{a}}$ & Housewives ${ }^{b}$ & Students $^{\mathrm{a}}$ & Housewives $^{b}$ \\
\hline Headache remedy & 3.69 & $3.38^{c}$ & 3.32 & $2.98^{\mathrm{c}}$ & 2.73 & 2.42 \\
\hline Beer & 2.78 & $2.60^{c}$ & 3.68 & $3.08^{c}$ & 3.57 & $2.71^{\mathrm{c}}$ \\
\hline Color television & 3.94 & $3.84^{\mathrm{c}}$ & 3.65 & 3.51 & 3.69 & $3.43^{c}$ \\
\hline Clothing & 3.43 & 3.45 & 3.87 & $3.59^{c}$ & 3.93 & $3.61^{\mathrm{c}}$ \\
\hline Laundry soap & 3.16 & 2.99 & 2.75 & 2.53 & 2.47 & 2.42 \\
\hline Hamburger substitute & 2.96 & $2.56^{c}$ & 2.89 & $2.33^{c}$ & 2.27 & $1.93^{c}$ \\
\hline Automobile & 3.94 & 3.85 & 3.92 & $3.70^{c}$ & 3.97 & $3.65^{c}$ \\
\hline Furniture & 3.44 & 3.51 & 3.60 & 3.59 & 3.68 & 3.52 \\
\hline Facial soap & 3.06 & $2.89^{c}$ & 2.89 & 2.94 & 3.17 & $2.85^{c}$ \\
\hline Air conditioner & 3.78 & 3.75 & 3.17 & 3.21 & 3.21 & 3.14 \\
\hline Insurance & 3.81 & 3.71 & 3.41 & 3.38 & 3.23 & 3.08 \\
\hline Mouthwash & 3.05 & 2.92 & 3.24 & 3.02 & 3.27 & $2.57^{c}$ \\
\hline Coffee & 3.08 & 2.88 & 3.64 & 3.28 & 2.72 & 2.58 \\
\hline Refrigerator & 3.67 & 3.70 & 3.16 & 3.23 & 3.16 & 3.14 \\
\hline Physician selection & 3.89 & $3.72^{c}$ & 3.67 & 3.50 & 3.28 & 3.18 \\
\hline Canned peaches & 2.47 & 2.49 & 2.71 & 2.54 & 1.97 & 1.99 \\
\hline Radio & 3.34 & 3.16 & 2.94 & 2.79 & 2.85 & 2.64 \\
\hline Detergent & 2.98 & 2.88 & 2.43 & 2.35 & 2.47 & 2.17 \\
\hline Books or magazines & 3.18 & 3.00 & 3.46 & 3.36 & 3.44 & $3.08^{c}$ \\
\hline Cigarettes & 3.00 & $2.49^{c}$ & 3.14 & $2.68^{c}$ & 3.33 & $2.51^{c}$ \\
\hline
\end{tabular}

This score is based upon examination of the entire student sample.

b This score is based upon examination of the 100 housewives sample.

${ }^{\prime} t$ test is significant at the .05 level.

students. Unlike the two cases where student and housewife responses were compared, these differences were not consistent and did not lead to meaningful interpretation. Identification of the factors causing response differences between the two locations is beyond the scope of this study and at this point would only be speculation. Observation of these differences does, however, illustrate the importance of response setting control in comparing the responses of two populations.

Some may be surprised by finding reference group influences on housewives significantly greater than that on students for products like furniture, where presumably housewives are more likely to be making purchases. The measures used were designed to indicate the degree of reference group influence in selecting the appropriate alternative given that the product is to be purchased. In the theoretical section of this paper, three reasons were presented for expecting the reference group influence upon students to be greater than that upon housewives. We believe that these arguments are in no way diminished for products (like furniture) where housewives are likely to have more experience and information than students.

The findings do not suggest that reference group influence differences between students and housewives should hold across all types of situations. Rather, the results suggest that students, when compared to housewives, are (a) more likely to be receptive to reference group influence given the particular product, or (b) more receptive to reference group influence for a larger number of product cases.

Much of the experimental research conducted in psychology and consumer behavior has used college students as respondents. The results of this study illustrate the danger in generalizing the findings of studies using business students as subjects to other populations.

\section{APPENDIX}

The construct validity of the 14 manifestation statements was measured using the Campbell and Fiske (1959) test which examines both the convergent and the discriminant properties of the methods in question. This procedure calls for the construction of multitrait-multimethod correlation matrices which show the intercorrelations among scores for at least two different traits each examined using at least two different measures. (For a given type of reference group influence, the corresponding subset of manifestation statements in the exhibit represents what Campbell and Fiske refer to as methods, i.e., measures. A trait in these matrices is a specific product.) ${ }^{9}$

Data on only canned peaches and automobiles were included in the validation tests primarily because examination of two products presumably opposite in reference group influence would sufficiently satisfy the

${ }^{9}$ See Silk (1971) for more specific information on this construct validation approach. 
test for discriminant validity and examination of more than two products, or traits, would unnecessarily complicate the computations. ${ }^{10}$

Convergent validity can be tested by examining the inter-item correlations between measures of the same trait. The number of significant (at the 0.01 level) interitem correlations for canned peaches and automobiles, respectively, for the three types of reference groups are: informational -10 of 10 and 7 of 10 ; utilitarian -6 of 6 and 4 of 6 ; and value-expressive -10 of 10 and 10 of 10 .

Several criteria are evidence of discriminant validity. First, the correlation between a measure and another measure on the same trait should be greater than the correlation between that measure and any other measure having neither trait nor method in common. This criteria for the three reference group types was met for automobiles and canned peaches, respectively, as follows: informational -70 of 80 and 80 of 80 ; utilitarian-34 of 36 and 34 of 36 ; and value-expressive -80 of 80 and 79 of 80 .

The second test of discriminant validity is that a measure should have a higher correlation with other (but different) measures of the same trait than with scores obtained when the same measure is used on different traits. For the informational, utilitarian, and value-expressive reference groups, respectively, this second criteria was met for automobiles 12 of 20,9 of 12 , and 17 of 20 times and for canned peaches was met 20 of 20,11 of 12 , and 16 of 20 times.

\section{[Received April 1977. Revised June 1977.]}

\section{REFERENCES}

Albert, Bernard (1967), “Non-Businessmen as Surrogates for Businessmen in Behavioral Experiments," Journal of Business , 40, 203-7.

Arndt, J. (1971), "A Research Note on Intergenerational Overlap of Selected Consumer Variables," Markeds Kommunikasjon, 3, 1-8.

Asch, S. (1952), Social Psychology, Englewood Cliffs, N. J.: Prentice Hall.

Berning, Carol A., and Jacoby, Jacob (1974), "Pattern of Information Acquisition in New Product Purchases," Journal of Consumer Research, 1, 18-22.

Bourne, E. S. (1956), "Group Influences in Marketing and Public Relations," in Some Applications of Behavioral Research, eds. R. Likert and S. P. Hayes, New York: UNESCO.

Brim, O. G. (1968), “Adult Socialization,” in Socialization and Society, ed. J. Clausen, Boston: Little, Brown \& Co.

Bruner, J. S. (1958), "Social Psychology and Perception,"

\footnotetext{
${ }^{10}$ Although the construct validity tests presented are based upon the responses of the 100 housewives, multitrait-multimethod correlation matrices were also constructed for the 88 student subjects and are very similar to those for the housewives.
}

in Readings in Social Psychology, eds. E. F. Maccaby, T. M. Newcomb, and E. L. Hartley, New York: Holt, Rinehart and Winston, 85-93.

Campbell, Donald T., and Fiske, Donald W. (1959), “Convergent and Discriminant Validation by the Multi-traitMultimethod Matrix,"'Psychological Bulletin, 56, 81105.

Copeland, Ronald M., Francia, Arthur J., and Strawer, Robert H. (1973), "'Students as Subjects in Behavioral Business Research," Accounting Review, 48, 365-72.

Davis, Keith E. (1968), "Needs, Wants, and Consistency,", in Theories of Cognitive Consistency: A Sourcebook, eds. R. P. Abelson et al., Chicago: Rand McNally \& Co., 327-30.

Deutsch, M., and Gerard, H. B. (1955), "A Study of Normative and Informational Social Influences upon Individual Judgment," Journal of Abnormal and Social Psychology, 51, 624-36.

Durkheim, Emile (1951), Suicide, trans. George Simpson, New York: Free Press.

Enis, Ben M. (1974), Marketing Principles, Pacific Palisades, Calif.: Good Year Publishing Company, Inc.

, Cox, Keith K, and Stafford, James E. (1972), "Students as Subjects in Consumer Behavior Experiments," Journal of Marketing Research, 9, 72-4.

- and Stafford, James E. (1964), "Consumer's Perception of Product Quality as a Function of Various Informational Inputs, Proceedings, Fall Conference, American Marketing Association, 340-4.

Feather, N. T. (1971), "Organization and Discrepancy in Cognitive Structures," Psychological Review, 178, 355-79.

Hochbaum, G. M. (1954), “The Relation Between Group Members' Self-Confidence and Their Reactions to Group Pressures to Uniformity,"'American Sociological Review, 19, 678-87.

Hovland, C. I., Janis, I. L., and Kelley, H. H. (1953), Communication and Persuasion, New Haven, Conn.: Yale University Press.

- and Weiss, W. (1951), "The Influence of Source Credibility on Communication Effectiveness,"' Public Opinion Quarterly, 15, 635-50.

Janis, I. L., et al. (1959), Personality and Persuasibility, New Haven, Conn.: Yale University Press.

Hyman, H. H. (1942), "The Psychology of Status," Archives of Psychology, 38, 15.

Jacoby, Jacob, Speller, D. E., and Kohn, Carol A. (1974), "Brand Choice Behavior as a Function of Information Load: Replication and Extension,"' Journal of Consumer Research, 1, 33-42.

Jahoda, Marie (1972), "Conformity and Independence: A Psychological Analysis,', in Behavioral Science Foundations of Consumer Behavior, ed. Joel Cohen, New York: Free Press, 339-54.

Johnson, Harry M. (1960), Sociology: A Systematic Introduction, New York: Harcourt Brace Jovanovich, 557-8.

Jones, Edward E., and Gerard, Harold B. (1967), Social Psychology, New York: John Wiley \& Sons.

Jones, E. E., Kanouse, D. E., Kelley, H. H., Misbett, R. E., Valins, S., and Weiner, B. (1972), Attribution: Perceiving the Causes of Behavior, Morristown, N.J.: General Learning Press.

Kanter, Donald L. (1970), “Pharmaceutical Advertising and 
Youth," unpublished paper, Coronada Unified School District, Coronado, Calif.

Katz, Daniel (1968), "Consistency for What? The Functional Approach," in Theories of Cognitive Consistency: A Sourcebook, eds. R. P. Abelson et al., Chicago: Rand McNally \& Co., 179-91.

Kelman, H. C. (1961), "Processes of Opinion Change,' Public Opinion Quarterly, 25, 57-78.

, and Baron, Reuben M. (1968), "Determinants of Modes of Resolving Inconsistency Dilemmas: A Functional Analysis," in Theories of Cognitive Consistency: A Sourcebook, eds. R. P. Abelson et al., Chicago: Rand McNally \& Co., 670-83.

Khera, Inder P., and Benson, James D. (1970), "Are Students Really Poor Substitutes for Businessmen in Behavioral Research?' Journal of Marketing Research, 7, 529-32.

Kogan, N., and Wallach, Michael A. (1967), "Risk Taking as a Function of the Situation, the Person, and the Group," in New Directions in Psychology III, New York: Holt, Rinehart \& Winston.

Levitt, Theodore (1965), Industrial Purchasing Behavior, Boston: Harvard University.

Reisman, D., and Roseborough, H. (1955), "Careers and
Consumer Behavior," in Consumer Behavior Vol. II, The Life Cycle and Consumer Behavior, ed. Lincoln Clark, New York: New York University Press.

Rosenberg, M. J. (1968), "Hedonism, Inauthenticity, and Other Goals Toward Expansion of a Consistency Theory,"' in Theories of Cognitive Consistency: A Sourcebook, eds. R. P. Abelson et al., Chicago: Rand McNally \& Co., 73-111.

Scott, Ward (1974), "Consumer Socialization," Journal of Consumer Research, 1, 1-14.

Sheth, Jagdish N. (1970), "Are There Differences in Dissonance Reduction Behavior Between Students and Housewives?' Journal of Marketing Research, 7, 243-5.

Shuptrine, F. Kelly (1975), "On the Validity of Using Students as Subjects in Consumer Behavior Investigations," Journal of Business, 48, 383-90.

Silk, A. J. (1971), "Response Set and the Measurement of Self-Designated Opinion Leadership," Public Opinion Quarterly, 35, 383-97.

Teter, J. W. (1966), "The Family, Peers and Media Influence on Youth's Present and Future Consumption Preferences," unpublished thesis, Oklahoma State University, Stillwater, Okla. 